\title{
THE MILLENNIAL GENERATION AND POPULAR CULTURE IN EFL CLASSROOM
}

\author{
Farhanaz Rabbani \\ Department of English, University of Dhaka, Bangladesh \\ E-mail: fnazrs@yahoo.com
}

APA Citation: Rabbani, F. (2015). The millennial generation and popular culture in EFL classroom. Indonesian EFL Journal, 1(1). 88-97

Abstract: Writing instructors all over the world are facing new challenges in teaching writing to students who belong to the rapidly evolving digital age. These multitasking youngsters are popularly referred to as Generation Y or the Millennial Generation and are the most connected generation of the century. With the dissemination of digital communication, popular culture and online networking have become an integral part of Generation Y. Teachers need to address this connectedness and focus on a curriculum based on Communicative Language Teaching (CLT) where interactive activities are highlighted. The financially and technologically savvy Generation Y-ers want to use a discourse they are familiar with and work with materials on popular culture. This paper shows the necessity of popular culture in teaching literature and academic writing courses to the Generation Y students because popular culture is the new global culture. Teachers need to use classroom materials and resources for formal, informal discourse and computer mediated discourse (CMD).

Keywords: millennial generation, communicative language teaching, computer mediated discourse

\section{INTRODUCTION}

Teaching writing has been a challenge to instructors throughout the ages. It has gone through stages of evolution and experimentation over the past few decades. But the most interesting developments in language research happened in the late nineteenth century when Berlitz proposed The Direct Method which placed more importance to oral lessons and spontaneous participation of the students in their target language. In the 1950s, the Audio-lingual Method used the basic tenets of Berlitz's method and added the use of tapes and visual aids in lessons. These changes eventually led to the emergence of the Communicative Language Teaching (CLT) which advocates that learning is an intuitive process that needs the proper conditions to flourish (Howatt, 2004, p.192). Throughout these trials in teaching methods, teachers and instructors overlooked critics and skeptics because they had only one goal: to determine the best way to teach English effectively to a target group or students (Howatt, 1984, p.298). Teachers have a natural inclination to protect academic discourse from outside influences (brought in by students). But, today, the process of enforcing students to learn knowledge in the traditional manner collides with the discourse they use at home and on the internet, thereby creating an ineffective learning environment. This realization prompts a teacher to remediate himself in order to understand new disciplines and understand the psychological orientation of students (Shaughnessy, 1999, p.94). Therefore, along with remediating themselves, teachers also have to redesign learning environment, lesson plans and materials.

When Latin was taught in the $16^{\text {th }}$ century, it was accompanied by Anglo Saxon translations and classroom exercises based on the more familiar aspects (for example, farming, hunting) of the students (Howatt, 1984, p.5). Much later, when CLT gained momentum, teachers began to provide simulated learning situations both in and out of classrooms (Mukalei, 1998, p.97). In order to create these learning situations, it is essential to know which discourse the 
students are more comfortable with. Students today, especially those belonging to Generation Y, use and encounter several types of discourses. Generation Y refers to people who were born between 1981 to 1999. Rhetorical theories have repeatedly addressed the problems of familiarizing students with academic discourse or formal English, as opposed to home discourse or informal English. But, in the $21^{\text {st }}$ century, it is not only home discourse that acts as a resistance to academic discourse. Students today are overwhelmingly immersed in the digital media where popular culture dominates their thoughts, their attitudes and their actions. These students belong to Generation Y and share some common traits like obsession with popular From the cultural point of view, based on Gramsci's 'hegemony', it is necessary to create an "educative alliance" between high culture and popular culture so that one establishes "an organic unity between theory and practice, between intellectual strata and popular masses, between rulers and ruled which constitute democratic centralism" (Forgacs, 1999: 218).

Therefore, the classroom must have interpersonal communication between teachers and students, based on sociocultural attitudes (Breen and Candlin, 2002: 90-91). In recent years, studies have been conducted on using elements of popular culture in EFL and ESL classrooms both in secondary and tertiary levels. Domoney and Harris (1993) conducted workshops in Mexico on the use of pop music, especially rap music, in English language classrooms. They state that instead of treating rap music as 'discreet' or 'marginal items', it should occupy a more 'central' role in classrooms. Cheung (2001) suggests the use of popular movies like Armageddon and Terminator 2 to teach concepts of self sacrifice both in humans and robots in English classrooms of Hong Kong. But, so far the focus of these studies was only on popular culture, but not specifically on the impact of popular culture on Generation Y. I believe that it is necessary to reinforce the significance of stimulation found in popular and digital culture and its role in the Generation Y writing classroom because it has completely changed the motivational nature of students. The paper focuses, firstly, on the need for writing teachers to analyze the social and psychological orientation of the Generation Y students and secondly, proposes effective ways of using popular culture specifically through the print media, non-print media and online networking.

\section{SOCIO-POLITICAL ORIENTATION OF GENERATION $Y$}

Generation Y refers to those born approximately between 1975 to the late 1990s. Reilly (2012: 3) cites Lancaster and Stillman's survey and classifies the generations as: The Baby Boomer generation (1946-1964), Generation X (1965-1980), Generation $Y$ (1981-1999), Generation $Z$ (2000-present). Generation Y are the grandchildren of the Baby Boomers. Children of Generation X are also known as Echo Boomers, Millenium Generation, iGeneration, Google Generation etc. The term was originally coined as Generation 'Why' because they always question the 'command and control' attitudes of parents and authoritarian institutions like the government (Sheahan, 2011).

The oldest Generation Y students have witnessed the fall of the Soviet Union (1991), First Gulf War (1991), Return of Hong Kong to China (1997), the Death of Princess Diana (1997) and the Dot Com Bubble Burst (2000). They have seen the end of the cold war and the emergence of the anti terrorist campaign in Iraq. The younger Generation Y-ers have experienced Y2K, 9/11 Terrorist attacks (2001), Anthrax scare (2001), the Formation of the European Union (2002), the Catastrophic Tsunami of 2004, and Swine Flu (2009). These youngsters grew up monitoring the rapid boom in global communication and technology and consequently suffered through the sudden crash of the dot com businesses and the layoffs prompted by mergers of big companies. Therefore, they are more restless and skeptical of established norms. They are financially more cunning than their parents in their professions, usually triggering them 
to change jobs frequently. According to a survey by the Diversified Investment Advisors (2005), 37 percent of Generation Y members start saving for retirement before they reach the age of twenty five. Since they were raised by more protective parents, Generation Y students exhibit a heightened sense of narcissism. Twenge (2006) labels them as 'Generation Me' and specifies that they prefer to socialize through the digital world. With both parents working outside the home, this multi-tasking generation relies heavily on the internet and loves to work at home (Reilly, 2012).

After Arab Spring, it is evident that youngsters rely heavily on digital media to raise their voice against political and social institutional control. Along with digital dictionaries and thesaurus, students have access to a wide range of information online. Online social networking is used to share and adapt to the new popular culture. Writing classrooms should integrate these devices in the lectures and lessons provided by teachers. Hornby suggests a similar practice in the situational approach where the best method of teaching the meaning of language patterns is achieved by embedding them in simple situations and by enabling students to act out in class (Howatt, 1984).

Apart from the internet, a heavy dependence on other forms of digital media like TV has changed behavioral patterns of Generation Y members as well. Due to the intense competition between network TV and cable TV, Generation Y-ers have plenty of options to investigate. Instead of concentrating on one or two channels, they click on their remote controllers and 'surf' the channels just as they surf on the internet. Therefore, there is less 'sense of homogeneity' among these youngsters (Salt, 2007). The popular shows are often laden with excitement and suspense, exposing the brain to "constant bombardment of change" (Yan, 2006). Generation Y students have brains which are accustomed to rapid storytelling and stimulating scenes. But the continual exposure to external stimuli provided by new technologies sometimes results in a drastic change in human behavior (Saffo, 2007).

\section{WRITING AND CREATIVITY}

Sheahan (2011) points out: "Gen Y are the most connected people on the planet, and they want to work in places that reflect that level of connectivity". A classroom is also a work place to these students. Since these students can connect with the whole world in a fraction of a second, they regard the action of writing essays tenaciously in classrooms redundant. Although this change is a cause of concern for many teachers, Gee and Hayes (2011: 1) view these changes from a historical perspective. They state that "digital media 'power up' or enhance the powers of language, oral and written, just as written language 'powered up' or enhanced the powers of oral language". Whenever a new software is developed, Generation Y adopts and adapts it to their needs, paving the way to create and distribute in the media without any cost. Creativity does not mean hours of planning, organizing and drafting a written piece.

According to Saffo (2007), Generation Y is always engaged in acts of micro-creation whenever they leave a comment on Amazon.com, on different blogs, or posting home-made videos on YouTube. A blog is a weblog dedicated to various issues or personalities. Anyone can type in a comment on a blog and share their ideas with others online. YouTube is the free video sharing where users can share or upload videos. Thus the whole concept of creativity has shifted from the traditional, pre-conceived definition to a new digital definition. From the behaviorist perspective, Generation Y students engage in metadiscursivity because they are accustomed to navigate through various discourses- formal, informal and digital at the same time (Moje et al., 2008). As a result common national cultures are fraying (Anderson, 2007). For example, YouTube shows how, in Anderson's words, a "massively- parallel culture" is taking the place of common culture. As Bhabha relates: "Youth in the millennial world of high speed information transfer lie in the in between of 
global and local spaces" (Moje, 2002). Generation Y youngsters are more globalized than any other generation so far and popular culture is the sole platform that unites them together.

\section{POPULAR CULTURE}

The word 'popular' is derived from a term used in the late Roman Republic'populares' which means 'favouring the people'. It was a political term used to reflect democratic ideologies of political parties. Today, popular refers to the quality of being well liked, well received and easy to understand. Therefore, popular culture implies the social and political practices which are widely liked by the masses or the ordinary people. It is a culture made by the people for themselves (Williams, 1999). In the history of English language teaching, much emphasis was given on formal and classical texts to facilitate students to acquire the necessary skills to communicate in a strictly formal environment. But with the introduction of CLT, the use of tape recorders, compact discs (CDs), television programs, and music began to be crucial parts of classroom activities. Gradually, contemporary music, movies and the digital media made their way into writing classrooms all over the world. Therefore, social interaction and conversation play dominant roles when popular culture is integrated into the language classroom.

\section{Popular culture and literacy}

Teaching youths in the $21^{\text {st }}$ century requires a deeper perception of youth literacy from the socio-cultural perspective. As Moje (2002: 108) asserts, literacy can never be well understood "unless one attends to people's literary practices-the values, the beliefs, and actions that people bring to reading and writing and to the multiple symbol systems and signs with which reading and writing of print are articulated". An absence of representations of the symbolic, visual and oral codes makes reading and writing very limited in scope (Moje et al., 2008). When the youngsters of Generation $Y$ use popular culture in the classroom, they read or watch to create and comment on new texts in different ways. According to Alvermann young people utilize popular cultural texts in "unpredictable ways" to make a sensible connection between the classroom and their own worlds. They also utilize popular culture to assert their identities in their communities (Moje, 2002: 116).

How to use popular culture in the classroom

For the convenience of the readers, I have divided the illustrations in three segments: print media, non print media and online networking. Popular culture is found in all of these three spheres. The print media includes newspapers, magazines, comics and best seller books. Non print media includes the whole gamut of digital entertainment, for example, television, movies, music (YouTube). Online networking includes social networks like facebook, twitter and blogs.

\section{Print media: Newspapers}

Apart from the prescribed texts, newspapers and magazines have been habitually used in writing and literature classrooms. Teachers can highlight current events and skillfully blend them into the lessons as authentic materials. In ELT, artificial or non-authentic materials are identified as prescribed texts which are more methodical and organized. Authentic materials in curriculum imply additional nontraditional materials which are used to bring students closer to the target language culture (Peacock, 1997: 144). In a classroom where newspaper articles and cartoons were sued as authentic materials, Peacock found that authentic materials "significantly increased learner on task behavior". Hodson (2008) mentions a series of British newspapers published during the 2008 Olympics. He used some of the following newspaper headlines to illustrate puns and wordplay:

- "Peach volleyball"[The Sun, 14 August]

- "It's oar-inspiring" [Daily Mirror, 18 August]

- "It's the Bei-bling Olympics" [The Sun, 18 August]

Although using authentic materials like these may be challenging for teachers, they 
however, provides students with a fresh outlook on language itself. Teachers can utilize the London Olympics 2012 and collect materials for language instruction in class.

\section{Print advertisements}

Print advertisements are available everywhere-on billboards and in newspapers and magazines. Since they are visually attractive, teachers can use advertisements to discuss different issues and attitudes of the current society. As Williams (1999) states, advertising has crossed the "frontier of the selling of goods and services and has become involved with the teaching of social and personal values". In figure 1, a print advertisement has the caption 'iPod....I'm your father'. This interesting advertisement focuses on the existence of the cassette tape long before iPod came into being. Generation Y students will be highly motivated to study this advertisement since they are very familiar with iPods. Teachers can ask students to discover the history of the cassette tape and link it to the development of the iPod. Students will learn researching skills and will be able to write essays on definition and classification of different technological tools over the past few decades.

\section{Cartoons}

Other visual aids like cartoons can be used as authentic materials to motivate and to aid in comprehension. Exercises with visual aids like cartoon strips not only captivate students, but also help to transcend first and second language barriers. Cartoons can be ideal authentic materials because they have intersting story lines, promoting discussions on theme, moral, and character analysis. Cartoon strips like Garfield, Peanuts, Charlie Brown and Dilbert may be used to highlight comedy, satire and symbolism. Editorial cartoons can be used as excellent resources for writing teachers. Editorial cartoons may be used to initiate a discussion of current events, to introduce writing assignment related to those events, and to design vocabulary exercises based on particular cartoon strips.

Figure 2 shows a cartoon published on June 26, 2008 in a Bangla daily newspaper The Daily Naya Diganta. The word on the huge hand implies the 'Rising prices of essential commodities' in Bangla. ESL and EFL students in Bangladesh who look at this cartoon will immediately feel comfortable because the text is in Bangla. As the figure shows, the price of essentials is creating a wrenching pressure on an ordinary citizen who, according to his attire, belongs to the middle class. Students may be asked to evaluate the significance of the wrench in the picture and how it is related to real life situations. The colour schemes, and the expression on the face of the little man in the picture may also be discussed to help them understand the context. Once students are in their comfort zone, teachers can give them writing assignments.

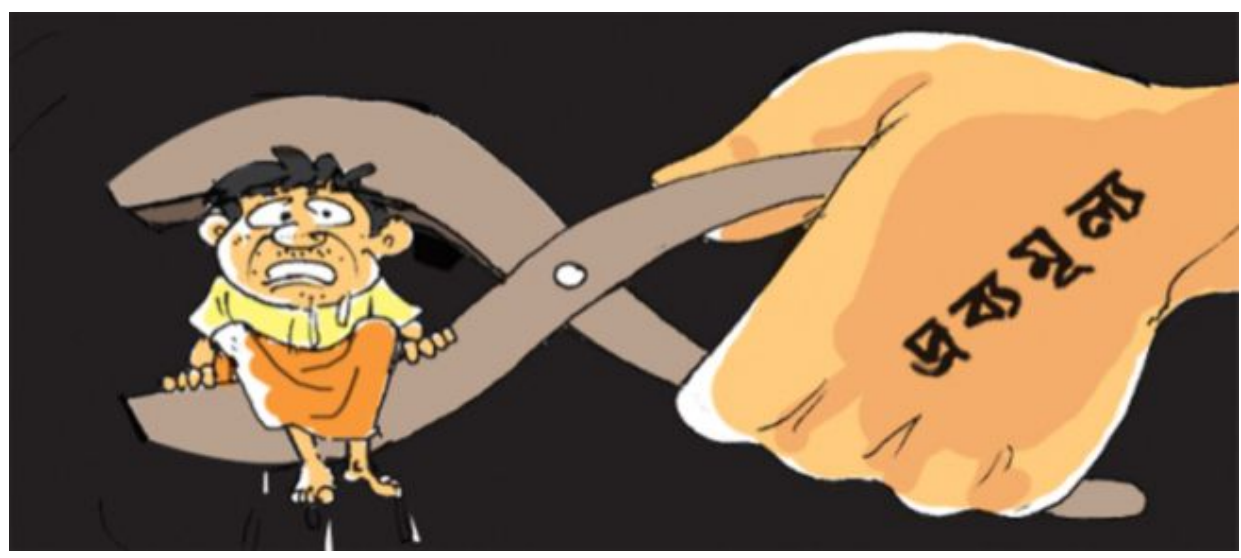

Figure 2. Editorial cartoon

(Source: http://editorialcartoon.files.wordpress.com/2008/06/cartoon1.jpg) 
For Generation Y students, manga offers a combination of text and image on paper. Manga are Japanese comics on paper and are often called graphic novels. This Japanese phenomenon is extremely popular with youngsters today specifically because of the stereotypical characters portrayed in them. Soon after Manga became popular, another form of cartoons-Anime came into being. Anime is characterized by colorful graphics and often have themes for an adult audience. Anime fans are a tight knit group who religiously follow their favourite characters on TV. Teachers may begin with the printed Manga and introduce other "meaning making" elements like Anime, or artwork or television interviews related to Manga. The same form of relationships between print and non-print forms can be found in other texts or documents used in classrooms (Mojo et al., 2008).

\section{Non-print media: Television cartoons}

Apart from print cartoons, television cartoons like 'The Simpsons' are widely popular for its satire and the symbolic representations of characters. While Homer epitomizes the stereotypical 'man' (foolish, dumb, materialistic yet innocent at the same time), his wife Marge symbolizes sophistication and intelligence. Their children's antics and comments can be used for animated discussions in the classroomwhere students can feel comfortable. Some episodes of 'The Simpsons' are based on classical texts like Lord of the Flies (Das Bus), A Streetcar Named Desire (A Streetcar Named Marge), Moby Dick (Diatribe of a Mad Housewife) etc. By showing the cartoons first, teachers can then show the original movies and ask the students to compare them. Students will feel more at ease to express their opinions and be more honest in their analysis.

\section{Movies}

Movies and videos in language instruction is strongly recommended in Communicative Language Teaching. Therefore, it is natural for teachers to use these materials as authentic materials in classrooms. Eken (2003) identifies the following literary elements that can be found in movies and films:

$\begin{array}{ll}\text { Narrative } & \text { Character } \\ \text { Setting } & \text { Theme } \\ \text { Signs } & \text { Genre }\end{array}$

After selecting a specific movie, teachers can guide students to discuss on any of these literary topics or focus on elements that are also found in TV and digital advertisements: cinematography, acting, colour schemes and design. Movies like 2012 (directed by Roland Emmerich, 2009) is a good example of how films can be used to motivate students to think about their society. As the world faces a catastrophe in the form of huge tsunamis and earth quakes, the huge ships carrying men from different races and some people paying billions of dollars to get inside the ship dwells on the darker sides of human nature.

Teachers can focus on any aspect of the movie and also encourage students to create a list of words commonly repeated in the movie. This enhances their listening, speaking and writing skills simultaneously. The chosen movie can also be compared to texts like Robinson Crusoe or Heart of Darkness. The following question may be asked to students: Identify the sections in the movie and the text where you find Commercial /human exploitation, internal conflicts or poignant imageries.

Students feel highly motivated and self learning occurs almost spontaneously. Once movies and videos are introduced in a classroom, the possibilities are endless. After completing their assignments on the movie 2012, students can watch the TV movie The Heart of Darkness (directed by Nicholas Roeg, 1993) and engage in a debate to determine whether book is better than the movie version. However, before showing any movie as a complimentary material to the text, it is essential for the teachers to ascertain that the movie corresponds to the written text (Whatley, 2012).

\section{Television shows}

Nowadays reality shows and sitcoms like Survivor and Friends are watched by almost 
all Generation Y-ers. Teachers can easily draw in students by referring to a well known situation in a sitcom like Friends and ask students to comment on the crisis, conflict or humour found in that particular scene. The Emmy winning sitcom The Big Bang Theory is another show that Generation Y students find enjoyable mainly due to the representation of their interests. According to statistics by CBS, in the show's third season premiere in 2009, The Big Bang Theory ranked as CBS's highest-rated show of that evening in the adults 18-49 demographic. This proves that The Big Bang Theory and the major characters in it are extremely popular among the Generation Yers. Sheldon Cooper, the geeky physicist who has an IQ of 187, is seen playing video games passionately completely disregarding what happens around him. This character trait appeals greatly to the narcissistic Generation Y students (Twenge, 2006), enabling them to engage in an interactive discussion on the character and his dialogues.

\section{Music}

In 1989, Griffee, in his preface to a special issue of The Language Teacher on Songs and Music, wrote: "As the Audiolingual method receded, we can also expect one of its children, the ESL songbook to recede with it. In its place will come an increased awareness of popular songs and music." His prophesy came true. Due to compact disks, MP3 and MP4, iPhones, iPads and YouTube, music is an integral part of the lives of the Generation Y. Whenever a song or a music video becomes 'viral' , it breaks down cultural and linguistic barriers and transforms into a global trend. The South Indian song "Kolaveri Di" is a good example because it was instantly translated into different languages by Generation Y youngsters. Most songs have themes that are related to love or emotions experienced frequently by listeners. Therefore, when Generation Y students listen to a song, they immediately try to connect the song to their own worlds. Murphey (1989) opines that songs can act as initiators of student interaction, thereby propagating the CLT approach in the classroom. The simple lyrics and repetitive structure of pop songs illustrate psycholinguistic and neuropsychological qualities which make the discourse extremely useful in the classroom. According to Millington (2011), songs can enhance: listening skills and pronunciation, speaking skills, vocabulary and grammar (cloze passages and using key words) and translation skills when EFL students translate it into their mother tongue.

Today, students of Generation Y listen to Lady GaGa and Beyonce. But teachers can use YouTube and refer to Linkin Park (Crawling), Bob Dylan (Like a rolling stone), John Lennon (Imagine), Eminem (Stan) and Josh Groban (You raise me up) in literature courses to illustrate concepts like imageries, dramatic elements, climax and crisis. Wallace (2009) proudly quotes Professor Belcher who said: "Today's popular culture is tomorrow's high culture," Belcher explained, adding, "Why not teach a popular form on the rise, rather than only after it has become respectable or moribund?"

\section{Online networking}

In using popular culture, teachers have to view students as a collective force, determine their preferences and choose the accurate context for a classroom. It will not be feasible to choose a song from a Judy Garland movie and expect the Generation Y students to feel enthusiastic about it. Teachers need to contemplate on motivating Generation Y by looking at them collectively as a highly connected generation who love to do networking online. Online networking via the internet is more focused on creating communities where people come together to collaborate, learn and build knowledge. Therefore, students take control of the content they want to use and the manner in which they want to use it. The teacher dominated classroom becomes obsolete and students make new connections and create new ideas through inquiry (McLoughlin, 2007). As Gee and Hayes (2011) point out, digital media is reshaping communication and therefore reshaping our classroom lessons. 
Taking advantage of online networking in a language classroom requires an indepth knowledge of computer mediated discourse (CMD). CMD, which is an essential component of computer mediated communication (CMC), is the communication produced by human beings when they transmit messages to one another through networked computers. In the past, teachers had to ward off informal discourse to emphasize on formal discourse. But in Generation Y classrooms, teachers have to negotiate with computer mediated discourse and find a middle ground to implement their lesson plans. I use the term 'negotiate' because in a networked classroom, teachers also need to understand the language applied in the virtual environment. As students communicate online, they create a language of their own. For example, LOL in emails and instant chat sites means 'laughing out loud'. Online networking has developed a 'metadiscourse' (discourse within discourse) or 'metalanguage' (Thurlow, 2006) for the teachers to examine before using computers as pedagogical tools in a writing classroom.

\section{Blogs}

There are several ways in which students can use online networking sites in a language class. A blog (or weblog) is a website in which items are posted and often focus on a particular subject, such as food, politics, or local news. Blogs are like online journals. According to Khampusaen (2012), blogs can be used as a pedagogical tool replacing pre-writing and drafting stages of writing. In a blog, teachers can write or attach a given essay for the students and ask them to leave a comment on that essay or literary piece. As more students comment on the blog, it will promote an online peer discussion. Teachers may use these blogs to guide the students to determine the various dimensions of the topic and the language used in the given essay. Generation $Y$ students will enjoy this exercise immensely.

\section{Twitter}

Twitter is an online social networking service and micro-blogging service that enables its users to send and read text-based posts of up to 140 characters, known as "tweets". For example, the following websites may be useful for instruction:

- twitaholic.com

- http://twitter.com/\#!/webenglishteach,

- http://wheretheclassroomends.com/teaching -logical-fallacies

\section{Podcasts}

Podcasts may also be used for writing exercises. Podcast is a parody of the traditional broadcast, the first 5 letters being replaced by the last 3 letters of iPod. BBC has very useful podcasts which reflect on different aspects of daily life. Students may either read or listen to podcasts and then proceed to answer the teacher's questions.

\section{Facebook}

Facebook is probably the most familiar social networking site for Generation Y. Facebook users can send instant messages/comments and upload visual aids easily. Facebook can be used in the following ways: events can be 'created', useful sites can be used for research by looking at the activity log, facebook community pages can be created and 'liked'. Clicking on the 'like' option is not just a passive activity. Generation Y students prefer to learn more from facebook than a dictionary of literary terms. Facebooking provides ample opportunities for research activities. For example, in Bangladesh, Tagore's songs are called Rabindra Sangeet. 'Rabindra Sangeet' on facebook has 273,000 likes. But on visitng this page, students encounter a list of 'similar' or 'related links' options. 'Baul Influences on Tagore' is in the 'related links' list provided in the Rabindra Sangeet page. Therefore, through facebooking, students not only learn more about the core topic, but they can also explore other related topics and issues in the 'related links 'option.

\section{CONCLUSION}

As the world becomes globalized, teachers have to attune themselves to the current trends and use them in the classroom. Having examined the various possibilities of using popular culture in the writing classroom, it is evident that just as 
Generation Y students are re-wired by popular culture and media, teachers can also be re-wired, retrained and remediated for the sole purpose of making the writing classroom more meaningful. But reshaping our classrooms requires extensive planning in both communicative language teaching (CLT) and computer mediated communication (CMC). In using popular culture, it is necessary to maintain a fine balance between authentic materials like songs, videos, and cartoons and artificial materials for the single purpose of effective teaching. In using the digital devices, teachers need to address issues related to computer mediated communication and the metadiscourse arising from instant messaging and social networking. Since the dimensions of the classroom and student teacher relationship are changing rapidly, it is extremely important to ascertain the perfect syllabus or curriculum that will aid Generation Y to be creative and effective in all the four skills. While we are rapidly moving on to the year 2020 , the urgency of such a change in the classrooms is intensifying, since the next cyber generation, Generation Z, will infiltrate writing classrooms all over the world to provide new challenges to writing teachers.

\section{References}

Anderson, C. (2007). Massively Parallel Cultures. In The impact of digitalization: a generation apart. 2007 KPMG International. Retrieved from http://www.kpmg.com/

CN/en/IssuesAndInsights/ArticlesPublications/ Documents/impact_digitalization_0_0701.pdf.

Breen,M.P. \& Candlin,C.N. (2002). The Essentials of a communicative curriculum in language teaching. Applied Linguistics 1(2) Retrieved from http://biblioteca.uqroo.mx/hemeroteca/applie d_linguistics/full_text/Volume-01-02-June1980/breen.pdf

Cheung, C.K. (2001).The use of popular culture as a stimulus to motivate secondary students' English learning in Hongkong. ELT Journal, 55(1).

Diversified Investment Advisors (2005). New diversified survey reveals vast majority of 'Generation $Y$ ' is concerned with saving for retirement; nearly half of Gen Y adults consider retirement benefits a very important factor in Choosing a Job. Retrieved from http://www.businesswire.com/news/home/20 050914005760/en/Diversified-Survey-RevealsVast-Majority-Generation-Concerned
Domoney, L. \& Harris, S. (1993). Justified and ancient: Pop music in EFL classrooms, ELT Journal 47(3).

Eken, A.N. (2003) You've got mail. ELT Journal 57(1). 51-59

Forgacs, D. (1999). National-popular: Geneology of a concept. In S. During (Eds), The cultural studies reader, $2^{\text {nd }}$ edition, p.210-219, Routledge, NY, USA.

Gee, J. P. \& Hayes, E. R. (2011). Language and learning in the digital age. New York: Routledge.

Hodson, R.J. (2008). Media humour in the language classroom. Proceedings of the CLS International Conference (CLaSIC), 4-7 December 2008, Singapore.

Howatt, A.P.R. (1984). A history of English language teaching, $1^{\text {st }}$ edition Oxford: Oxford University Press.

Howatt, A.P.R. \& Widdowson, H.G. (2004) A history of English language teaching, $2^{\text {nd }}$ edition. Oxford University Press.

Khampusaen, D. (2012). Collaborative blogging: A Tool for Teaching Writing in EFL Classroom. Proceedings of the 2012 International Conference on Education and Management Innovation, IPEDR vol.30, IACSIT Press, Singapore.

McLoughlin, C. \& Lee, M. J. W. (2007) Social software and participatory learning: Pedagogical choices with technology affordances in the Web 2.0 era. Proceedings ascilite Singapore: p.664-675

Millington, N.T. (2011). Using Songs Effectively to Teach English to Young Learners. Language Education in Asia, 2(1), 134-141.

Moje, E. B. (2002). But where are the youth? On the value of integrating youth culture into literacy theory. Educational Theory, 52(1).

Moje, E.B., Overby, M.,Tysvaer, N. \& Morris, K. (2008). The complex world of adolescent literacy: Myths, motivations, and mysteries. Harvard Educational Review, 78 (1).

Mukalel, J. C. (1998). Approaches to English Language Teaching. New Delhi: Discovery Publishing House.

Murphey, T. (1989). The top forty for teachers (in no special order). The Language Teacher XIII: 5

Peacock, M. (1997). The effect of authentic materials on the motivation of EFL learners. ELT Journal, 51(2), 144-153.

IPEDR, 2012 International Conference on Education and Management Innovation IPEDR (International Proceedings of Economics Development and Research (IPEDR) (ISSN: 2010-4626) vol.30 (2012) (C) (2012) IACSIT Press, Singapore (International Association of Computer Science and Information Technology). Retrieved from http://www.ipedr.com/vol30/32 ICEMI\%202012-M00059.pdf.

Reilly, P. (2012). Understanding and teaching generation Y. English Teaching Forum 1.

Breen, M and Candlin, C. (1980). The essentials of the communative curriculum in language teaching. Applied Linguistics, 1(2). 
Saffo, P. (2007). The Prana of the Internet. In The Impact of Digitalization: a generation apart. 2007 KPMG International. Retrieved from http://www.kpmg.com/ CN/en/IssuesAndInsights/ArticlesPublications/ Documents/impact_digitalization_0_0701.pdf.

Salt, B. (2007). Generation Y: Technology's latest gatekeepers. In The impact of digitalization: $a$ generation apart. 2007 KPMG International. Retrieved from

http://www.kpmg.com/CN/en/IssuesAndInsig hts/ArticlesPublications/Documents/impact_di gitalization_0_0701.pdf

Shaugnessy, M. P. (1999). Diving in: An introduction to basic writing. In E. Corbett, P.J. Edward, N. Myers, \& G. Tate (Eds), The Writing Teacher's Sourcebook. 4th edition, Oxford University Press, NY.

Sheahan, P. (2011). Generation Y in Asia: In the face of a talent crisis, companies are facing up to the challenges of the world's most powerful emerging consumers, clients and employees. Retrieved from http://worldwide.streamer.espeakers.com/asse ts/9/8099/30062.pdf

Storey, J (1950). Cultural theory and popular culture: An introduction. $3^{\text {rd }}$ edition, Prentice Hall, UK.
Thurlow, C. (2006). From statistical panic to moral panic: The metadiscursive construction and popular exaggeration of new media language in the print media. Journal of Computer-Mediated Communication, 11(3), article 1.

Twenge, J. M. (2006). Generation Me: Why today's young Americans are more confident, assertive, entitled-and more miserable than ever before. Free Press, a division of Simon \& Schuster, Inc. April 2006

Wallace, S. (2009, December 03). Pop Culture in the Classroom. In The Daily Princetonian. Retrieved from http://www.dailyprincetonian.com/2009/ 12/03/24620/print/.

Whatley, H.D. (2012) The effective use of motion pictures in the ESL Classroom. Journal of Arts, Science \& Commerce 3(2). Retrieved from www.researchersworld.com.

Williams, R. (1999). Advertising: The magic system. In S During (Eds), The cultural studies reader, $2^{\text {nd }}$ edition. Ne York: Routledge.

Yan, S. (2006). Understanding generation Y. in The Oberlin Review. Retrieved May 03, 2012 from http://www.oberlin.edu/stupub/ocreview/200 6/12/08/features/Understanding_Generation_ Y.htm. 